\title{
Jordens atmosfceriske iltning - klimaeffekter og konsekvenser
}

Af professor Robert Frei, Institut for Geografi og Geologi Københavns Universitet

Det er i dag en alment accepteret teori, at iltningen af Jordens atmosfære var en enorm, drivende kraft for klimaændringer, og at den havde voldsomme konsekvenser for livets udvikling på vor planet. At forstå dén kompleksitet og vekselvirkning, der eksisterer mellem forskellige parametre og cykler i Jordens system, er meget vigtigt bl.a. for at kunne tackle årsager til de mere recente klimatiske fluktuationer inden for de sidste 100.000-150.000 år, som ikke er menneskeskabte.

Der er derfor meget stor interesse for at kigge nærmere på årsagerne til fortidige klimaændringer specielt på geologisk tidsskala, hvor vi har indikationer på omfattende istider og/eller for næsten eksplosionsagtige evolutionspulser af nye livsformer.

Gruppen ved Nordisk Center for Jordens Udvikling (NordCEE), som forfatteren er en del af, arbejder netop med dette tema som hovedinteresse. Centerets forskningsdiversitet, der omfatter geologi, geo-biologi, palæontologi og geokemi, giver mulighed for en mangefacetteret tilgang til forståelsen af de
En kunstners opfattelse af Jordens overflade under Hadal-ceonen. Som følge af den høje temperatur i Jordens indre og vulkansk aktivitet udsendte skorpen halogengasser, ammoniak, brint, kuldioxid, metan, vanddamp og andre gasser. I de første 100 millioner år samlede disse gasser sig og dannede ur-atmosfceren. Den oprindelige atmosfcere menes at have nået et tryk på 250 atmosfcere og ville have varet yderst giftig at leve i. Da overfladen var afkølet tilstrcekkeligt, etablerede vanddamp fra vulkaner en vandcyklus. I begyndelsen fordampede regnen, når den ramte varm lava, men fordampningen afkølede gradvist Jordens oprindelige skorpe, indtil vandet kunne samles i fordybninger i Jordens overflade og danne oceaner. De

indbyrdes forhold af de mange parametre, som kan have spillet en rolle i udviklingen af klimaændringer på Jorden førhen.

De grovere hovedtræk af atmosfærens og oceanernes iltningshistorie er relativt velkendte; men der er stadig markante huller i vores viden specielt om iltningen af oceanerne, og mange af de processer, der var ansvarlige for de større overgange i oxidationstilstanden i atmosfære-hydrosfæresystemet, er stadig ikke helt kendte. I det følgende gives en kort sammenfatning af de vigtige perioder.

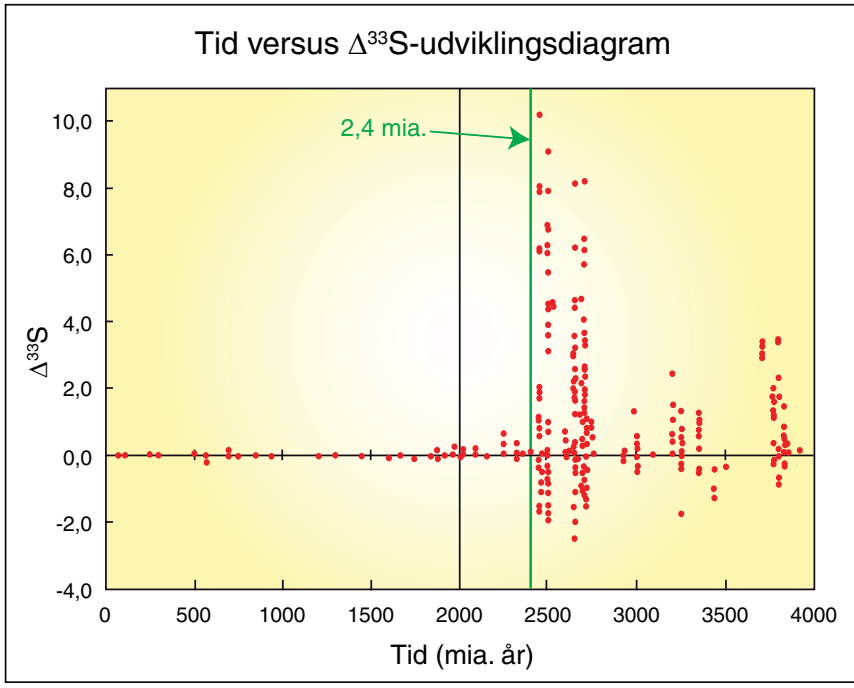

Tid versus $\Delta^{33} S-u d v i k$ lingsdiagram (cendret fra Farqaur og medforfattere ${ }^{2}$ ) afbilder det "skarpe" ophør af masseuafhcengig fraktionering af svovl for omkring 2,4 mia. år siden på tidspunktet for Den Store Iltkatastrofe. Dette kendetegn er foreløbigt blevet forklaret med etableringen af ozonlag, der var $i$ stand til at filtrere UV-lys og som følge heraf forhindrede foto-dissociationen af svovlgasser $i$ den tidlige

Jords atmosfcere. $\Delta^{33} S$ er defineret som $\delta^{33} S-0,515 \times \delta^{34} S$, hvor $\delta=\left(R_{\text {sample }} / R_{\text {standard }}-1\right) \times 1000$ og $R={ }^{34} S{ }^{\beta 2} S$ for $\delta^{34} S$ og $R={ }^{33} S{ }^{2} S$ for $\delta^{33} S$. (Grafik: UVH efter Farqaur og medforfattere ${ }^{2}$ )

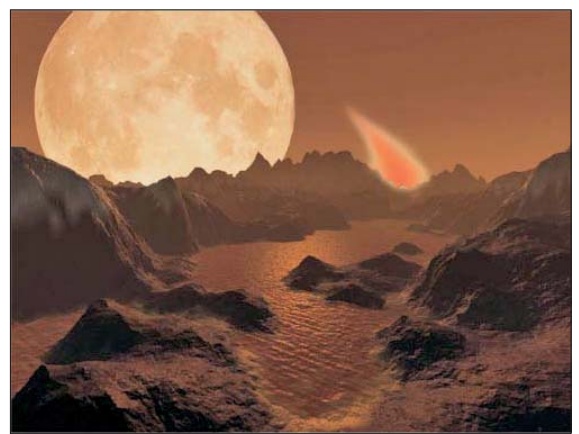

første flodsystemer blev dannet på de oprindelige kontinenter og de transporterede forvitringsmateriale fra højtliggende områder, som aflejredes pa bunden af de oprindelige have. (Illustration: Steven Hobbs, Brisbane, Queensland, Australien)

\section{Hadal-æonen}

Ikke meget kendes til Jordens atmosfære under den såkaldte Hadal-æon, som er perioden mellem Jordens tilvækst for 4,567 mia år siden og slutningen af det såkaldte "Late Heavy Bombardment" (det sene, kraftige bombardement) for ca. 3,85 mia. år siden, hvor Jorden blev kraftigt bombarderet af asteroider og meteoritter. Denne begivenhed var tilintetgørende både for de tidligste have og for eksisterende tidligt liv, der potentielt kan have eksisteret på Jorden før denne tid. Da der ikke findes geologiske bjergartsmateriale fra dén tid (de ældst bevarede bjergarter, der er dannet på Jordens overflade, de såkaldte skorpebjergarter, er 3,7-3,85 mia. år gamle og er blottede i Vestgrønland og i Slave-provinsen i Canada), bliver geologerne nødt til at støtte sig til indirekte spormetoder, primært isotopiske "optagelser", der er bevarede i meget modstandsdygtige mineraler, der overlevede den sene, kraftige bombardementsperiode, og som er indeholdt i sjældne, fx detritiske, korn, i yngre magmatiske og sedimentære bjergarter ( $\mathrm{fx}$ $\left.{ }^{1}\right)$. Brint og helium forventes kontinuerligt at sive ud fra atmosfæren, men manglen på de tættere ædelgasser i atmosfære, vi har i dag, antyder, at noget katastrofalt overgik den tidlige atmosfære. En teori siger, at dele af den unge planet blev splittet ad ved det sammenstød, der dannede månen, hvilket ville have resulteret $i$ en opsmeltning af store volumener af Jordens proto-skorpe. En temmelig stor del af materialet skulle være 


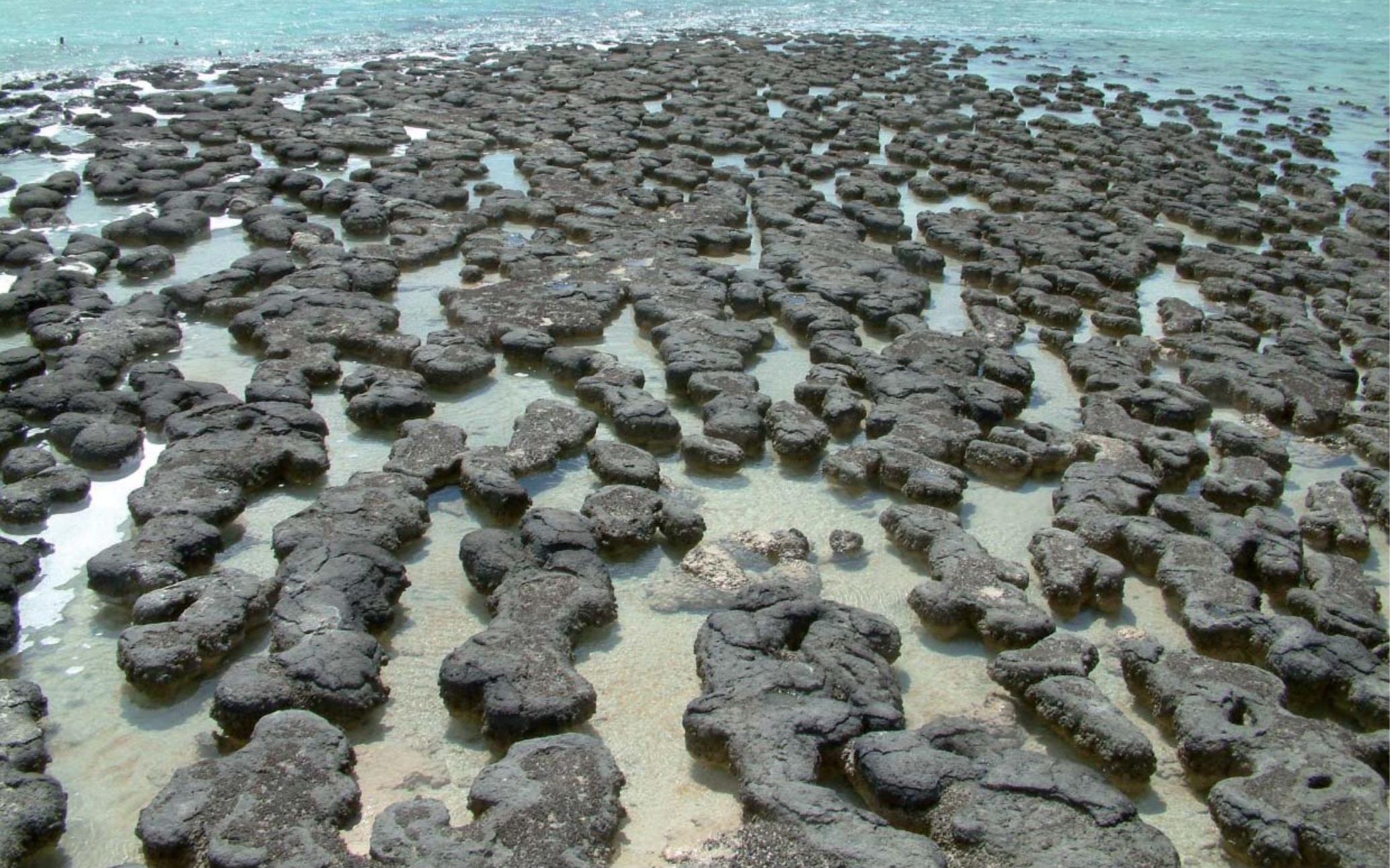

Nutidige udgaver af stromatoliske algekulturer, som var udbredt i Palceoproterozoikum. Det menes, at sådanne fotosyntetiske cyanobakterier ("blä-grønne alger") forårsagede Den Store Iltkatastrofe. Men det er mindre klart, om cyanobakterierne var produkter af palceoproterozoisk tid eller bare tilfceldigt fandt perioden meget gaestfri. Beviser fra biomarkører og forskellige geokemiske sporstudier antyder, at fotosyntetiske bakterier var til stede allerede på arkceisk tid. De tilgangelige palceoproterozoiske bjergartsoptegnelser fra mellem Den Store Iltkatastrofe og til for 2,2 mia. år siden udviser en forøgelse i oxidationsniveauet af mange grundstoffer. Stoffer som uran, svovl, jern og molybdcen, som har mere end et oxidationstrin, er tilbøjelige til at findes i reduceret form før palceoproterozoisk tid, hvorimod efter 2,2 mia. år er disse grundstoffer oftere koncentreret i de respektive sedimenter, hvilket antyder en større mobilitet i deres mere opløselige oxiderede form. Den mest naturlige forklaring på en forhøjelse af oxidationsniveauet for disse grundstoffer er en forøgelse af ilt $i$ atmosfceren ${ }^{18}$ og den heraf følgende forøgede forvitring af de landmasser, som var blottet i denne periode. Det er dog vigtigt at huske på, at denne oxidation sandsynligvis var begrcenset til atmosfceren og overfladevandet. I dybet og selv på relativt lavt vand på de ydre kontinentalsokler forblev oceanerne iltfrie. Iltningen af atmosfceren er også sat i forbindelse med mulige teorier om "Snebold Jorden"-isepisoder efter 2,4 og/eller 2,2 mia. år. (Foto: BrendanMc, www. panoramio.com)

Den aktive pladetektonik i Arkceikum skabte talrige, relativt små kontinentale landmasser, som var meget mobile, eftersom de flød på den turbulente kappe. Men hen imod slutningen af Arkcikum begyndte disse minikontinenter at smelte sammen. For omkring 2,5 mia. år siden ved Arkceikums slutning var der dannet et mere tektonisk stabilt superkontinent af sammensmeltede landmasser. De første fossile tegn på liv opstod i Arkceikum. Selvom livet sandsynligvis udvikledes for 3,8-3,6 mia. år siden som ikke-fotosyntetiske bakterier, er de celdste beviser for liv på Jorden 3,5 mia. år gamle fossiler fra Australien. Stromatolitter er fint lagdelte, tue-formede ansamlinger af mudder fanget af voksende måtter af blågrønne alger. Den arkciske atmosfcere, som de oprindelige organismer udviklede sig $i$, var sandsynligvis en reducerende atmosfcere af methan og ammoniak. I løbet af Arkcikum spredtes fotosyntetiske organismer, og atmosfceren blev mere iltrig. Tegningen er kunstnerens opfattelse af det arkceiske landskab. (Illustration: Peter Sawyer fra the Smithsonian Institution, Washington).

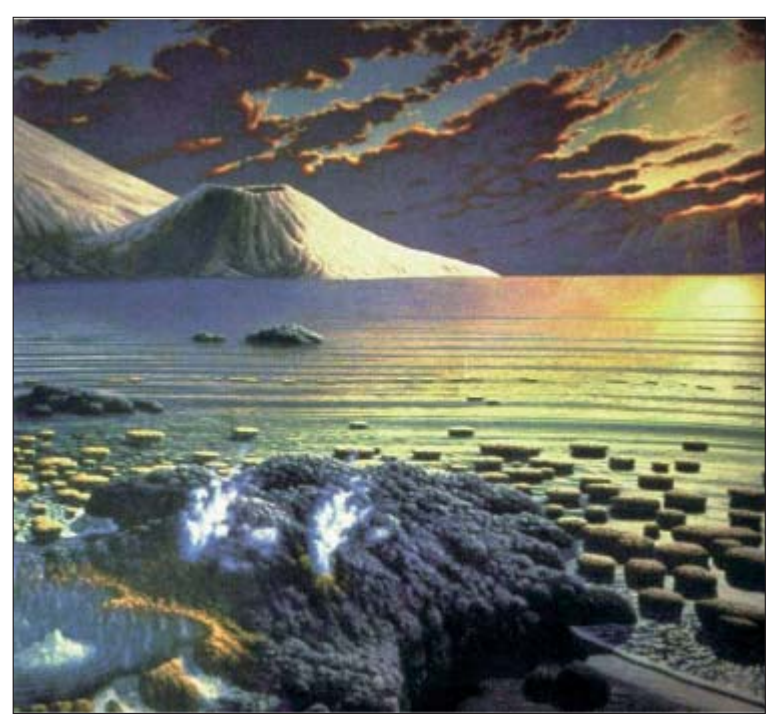


fordampet ved dette sammenstød og derved have skabt en "bjergartsatmosfære" på dampform omkring den unge planet. Efter kondensering af dampen blev varme volatiler ladt tilbage, hvilket formentlig resulterede $i$ en tung kuldioxidholdig atmosfære med brint og vanddamp. Eksistensen af en hydrosfære under denne tidsperoiode er genstand for megen debat, men en længere række af beviser argumenterer for eksistensen af flydende vand i Jordens meget tidlige historie (figuren øverst på side 14). Generelt antages det, at iltindholdet i Jordens tidlige atmosfære og i oceanerne var ekstremt lav, måske mindre end $0,0002 \%$ sammenlignet med nutidens $21 \%$, og at den derfor overvejende var reducerende.

\section{Tidsperioden mellem 3,85-2,45 mia. år}

Mange undersøgelser bekræfter, at iltniveauet forblev meget lavt $i$ tidsvinduet Arkæikum - tidlig Palæoproterozoikum. Denne konklusion blev underbygget og udvidet ved opdagelsen af en høj grad af masse-uafhængig fraktionering (mass-independent fractionation $=$ MIF) af svovlisotoper sulfider og sulfater i præ-2,45 mia. år gamle sedimentære bjergarter (figuren nederst på side 14). Systemet fungerer på den måde, at svovl udledes til atmosfæren fra vulkaner som $\mathrm{SO}_{2}$ og $\mathrm{H}_{2} \mathrm{~S}$, og herved fjernes de opløselige gasser som følge af nedbør ved dannelse af og afsættelse af sulfat og svovl på grundstofsform. Den kemiske oprindelse af MIF i svovl er stadig uklar. Farquhar og hans kolleger ${ }^{2}$ har i laboratorieeksperimenter vist, at fotodissociation af $\mathrm{H}_{2} \mathrm{~S}, \mathrm{SO}_{2} \mathrm{og}$ $\mathrm{SO}_{2} / \mathrm{CO}_{2} / \mathrm{H}_{2} \mathrm{O}$-blandinger alle producerer svovl på grundstofform med en bølgelængdeafhængig MIF-signatur. De eksperimentelle resultater, der bedst reproducerer MIF i svovlførende bjergarter ældre end $\sim 2,45$ mia. år, involverer fotodissociation ved enkelte bølgelængder $<200 \mathrm{~nm}$. I en virkelig atmosfære, som vi har i dag, vil MIF ikke blive produceret ved en enkelt bølgelængde, eftersom solstråling er fordelt på et bredt spektrum af bølgelængder.

Det er også blevet vist, at ozon $\left(\mathrm{O}_{3}\right)$ effektivt filtrerer UV-bølgelængder og derfor forhindrer fotodissociation af svovlgasser i atmosfæren, en proces der er forhindret af den atmosfære, vi har i dag. Nederste figur på side 14 viser en kompilation af $\Delta^{33} \mathrm{~S}$-værdier gennem tid, og figuren viser tydeligt, at $\Delta^{33} \mathrm{~S}$ stort set forsvinder for ca. 2,45 mia. år siden under en tidsperiode, hvor ilt blev almindelig i Jordens atmosfære (den såkaldte Store Iltkatastrofe, Great Oxidation Event; $\mathrm{GOE}^{3,4}$ ). Generelt set indikerer dette, at atmosfæren før for $\sim 2,45$ mia. år siden var karakteriseret af en mindre ozonbeskyttelse, og forholdene således var reducerende (figuren nederst side 15 viser en kunstners indtryk af, hvordan Jordens overflade kunne have set ud på dén tid).

Den simpleste forklaring på tilsynekomsten af $\mathrm{O}_{2} \mathrm{i}$ atmosfæren i koncentrationer ud over $0,0002 \%$ for $\sim 2,45 \mathrm{mia}$. år siden er, at
Diagram for relativ frekvens der viser sammenfaldet af store BIF-dannende perioder og større mantle plume-aktiviteter gennem Jordens historie $^{6}$. Jernberigelse af dybtliggende havvand menes knyttet til forøget hydrotermal, undersøisk aktivitet forbundet med høj kappe-varmegennemstrømning $i$ perioder med kappeopstigning. (Grafik: UVH modificeret efter Isley and Abott ${ }^{6}$ )

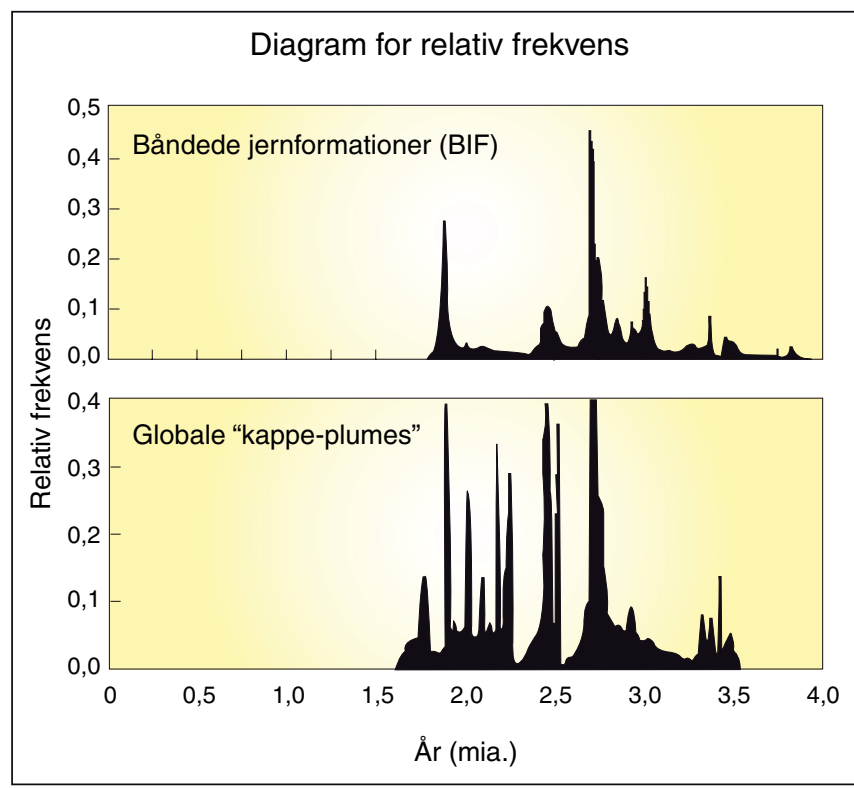

cyanobakterier, der benyttede sig af fotosyntese, udvikledes på dén tid. Dette anfægtes dog af nogle forskere, der antyder, at cyanobakterierne eksisterede mindst 300 mio. før slutningen af de store MIF-S-signaler.

"Produktion" af $\mathrm{O}_{2}$ ved fotosyntetiske processer:

$\mathrm{CO}_{2}$ (atmosfære) + sollys $\rightarrow$

$\mathrm{C}-\mathrm{H}$ sukker $+\mathrm{O}_{2}$ (atmosfære)
A. Aben minedrift I Sishen-minen, Sydafrika. Sishenjerminen er den syvende største jernproducent $i$ Verden og arbejder $i$ typisk palceoproterozoiske båndede jernformationer, der tilhører Transvaal Supergroup i Northern Cape Province $i$ Sydafrika. (Foto: Forfatteren)

B. Norbillede af båndet jernsten med typisk silikarige og jernrige mesobånd (Soudan Iron Mine, Minesota,USA. http://www.panoramio.com. Foto: Raymond Coveney)
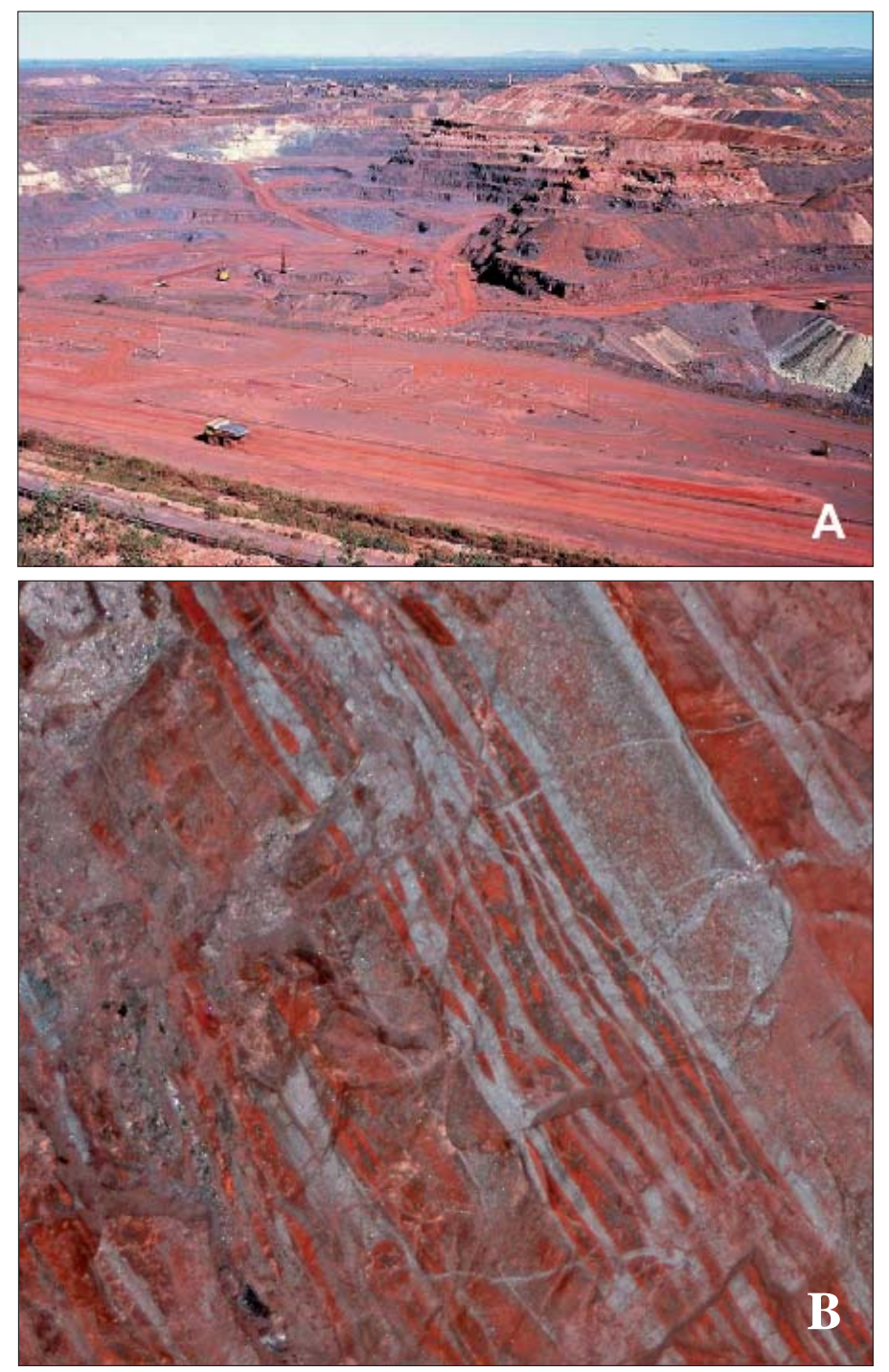

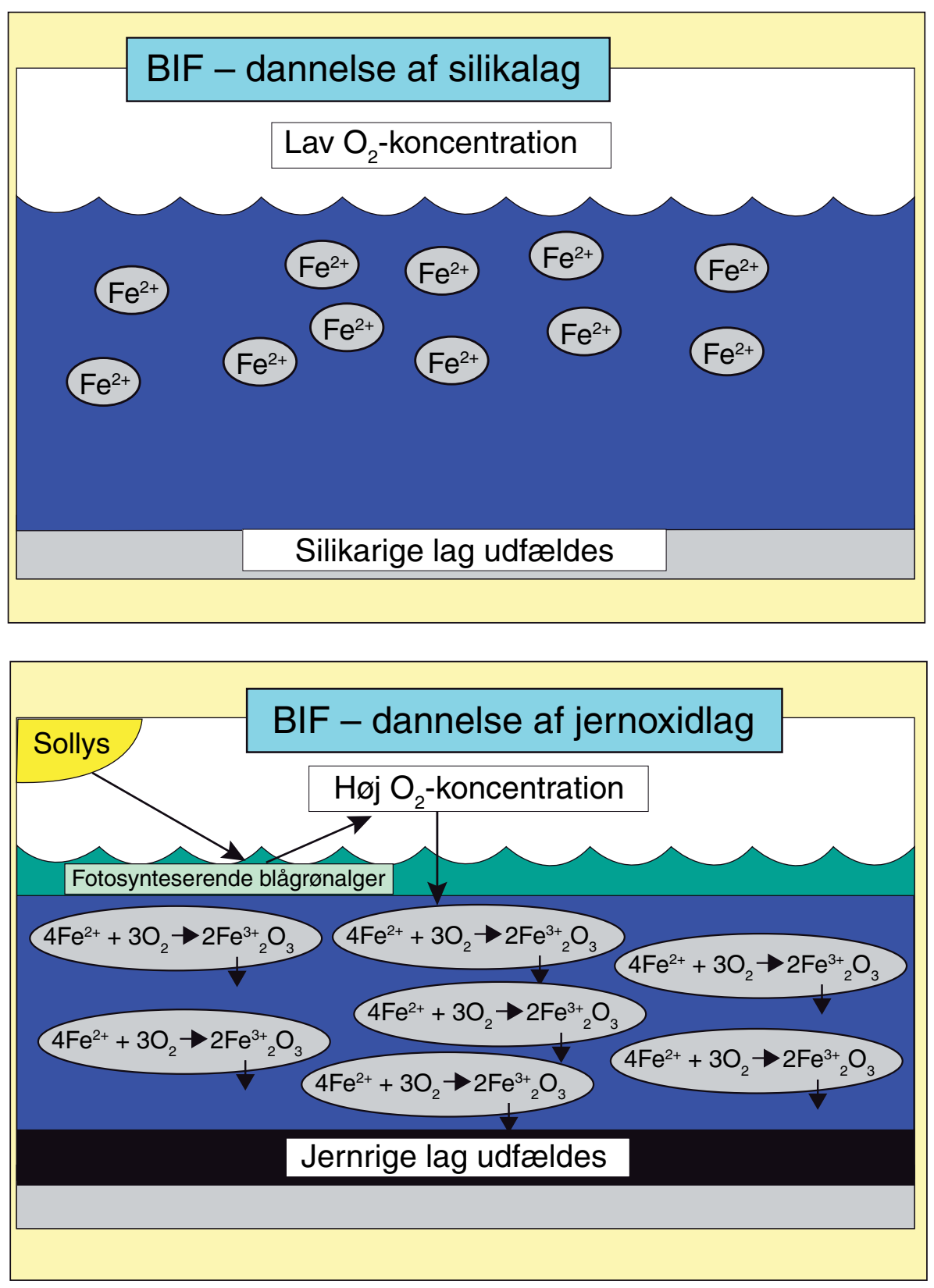

Skematisk diagram, der viser udfceldning af silika- og jernrige lag $i$ en typisk arkceisk-proterozoisk båndet jernformation. Opblomstring af blå-grønalger skaber ved fotosyntese forøgede iltkoncentrationer $i$ atmosfceren og $i$ lavt havvand, der bliver $i$ stand til at oxidere divalent opløseligt jern til dets trivalente uopløselige form. (Grafik: UVH modificeret efter forfatteren)

Perioden for 2,45 til 1,80 mia. år siden Store MIF-S-signaler optræder ikke efter perioden for $\sim 2,32$ mia. år siden, og i det mindste ud fra denne synsvinkel ser det ud som om, at atmosfærisk $\mathrm{O}_{2}$ uigenkaldeligt dukker op for mellem 2,41 og 2,32 mia. år siden. Årsagerne til denne forandring $\mathrm{i}$ atmosfærekemien diskuteres i vide kredse. Det nærliggende sammenfald for aflejringen af de båndede jernformationer (BIF: banded iron formation) fra sen Arkæikum med tilsynekomsten af atmosfærisk $\mathrm{O}_{2}$ er slående. Tidligt i Jordens historie indeholdt de dybe oceaner opløst jern $\left(\mathrm{Fe}^{2+}\right)$ påvist ved de omfattende aflejringer af båndede jernformationer. Dette forhold var et udtryk for - kombineret - lav atmosfærisk ilt og lave sulfatkoncentrationer for havvand.
Efter aflejringerne af BIF fulgte en hiatus (et "hul" i en geologisk lagserie, hvor der mangler aflejringer) på ca. 350 mio. år, før den store BIF-aflejring blev genoptaget for ca. 2,0 mia. år siden. Fuldstændig (dvs. global) erosion af BIF-sekvensen mellem 2,45 og 2,0 mia. år er mulig, men usandsynlig. Det er meget mere sandsynligt, at en iltning af atmosfæren og hydrosfæren for ca. 2,45 mia. år siden gav anledning til et egentligt omslag i Jordens system formentlig forårsaget af opblomstringspulser af cyanobakterier (figuren nederst på side 15 illustrerer en kunstners indtryk af, hvordan Jordens atmosfære kunne have set ud i løbet af denne periode) og såkaldte "plume-begivenheder" (opvældende kappe, som er etableret ved skorpe-kappegrænsen, og som forårsager en

\section{Geologisk tidsskala}

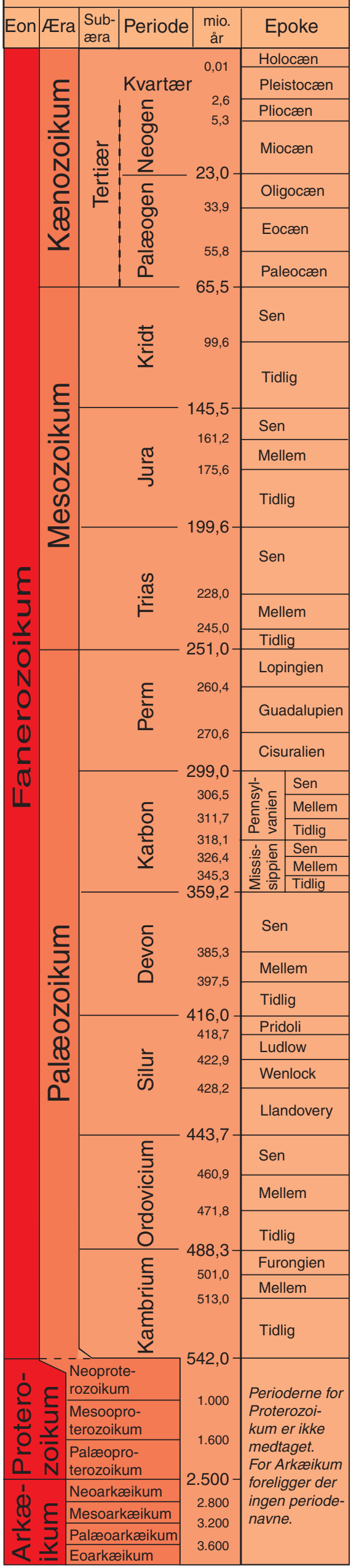


forøget varmestrøm, kappeopsmeltning og hydrotermale fluider fra undersøiske vulkanske skorstene), som korrelerer fint med forekomsten af BIF (figuren øverst på side 16). Aflejringen af BIF blev genoptaget fra $\sim 2,0$ mia. år siden og fortsatte indtil for $\sim 1,8$ mia. år ${ }^{6}$ siden; tilsyneladende stoppede aflejringen helt for ca. 1 mia. år siden.

\section{BIF og udforskning af den tidlige Jord} Båndede jernformationer er kemiske sedimenter med skiftende lag (i størrelsesorden $\mathrm{mm}$ til cm; figuren nederst side 16) af chert og jernholdige mineraler såsom hæmatit $\left(\mathrm{Fe}_{2} \mathrm{O}_{3}\right)$, magnetit $\left(\mathrm{Fe}_{3} \mathrm{O}_{4}\right)$, siderit $\left(\mathrm{Fe}_{2} \mathrm{CO}_{3}\right)$ og pyrit $\left(\mathrm{FeS}_{2}\right)$. Båndede jernformationer er primært fundet i prækambriske sedimentære sekvenser over hele Verden. Nogle af de ældste kendte bjergartsformationer dannet for mere end 3,7 mia. år siden indeholder båndede jernlag, og de båndede lag er almindeligt forekommende i sedimenter i Jordens tidligste historie. Adskillige jernformationerne findes i perioden for Den Store Iltkatastrofe (figur side 17), men forekomsterne bliver mindre almindelige efter for 1,8 mia. år siden. Det er problematisk at forklare genkomsten af dannelsesforholdene for BIF for 1,9 mia. år siden, og i forbindelse med "Snowball Earth-teorien" for 750 mio. år siden.

Almindeligvis antages det, at de båndede jernformationer blev dannet $i$ havvand som et resultat af iltfrigivelse fra fotosyntetiske cyanobakterier (blå-grønalger) kombineret med opløst jern i Jordens have, der sammen har dannet uopløselige jernoxider, som udfældedes og dannede et tyndt lag på overfladen, som kan have bestået af iltfrit mudder (der har dannet skifer og chert). Hvert bånd minder om et varv i den udstrækning, at båndingen menes at være resultatet af cykliske variationer i ilttilgængeligheden. Det er uklart, om de båndede jernformationer var årstidsbestemte, om de fulgte en slags feedback-svingninger i det komplekse havsystem, eller om de fulgte en helt anden cyklus. Det antages, at i begyndelsen var store mængder jern opløst i Jordens forsurede have. Med tiden, da fotosyntetiske organismer producerede ilt, blev det tilgængelige jern i Jordens have udfældet som jernoxider (figuren ovenfor). Ved det kritiske vendepunkt, hvor oceanerne permanent blev iltede, producerede små variationer i iltproduktionen pulser af fri ilt i overfladevandet vekslende med pulser af jernoxidaflejringer.

En anden dannelsesmekanisme for BIF er aflejring fra metalrige "brines" (meget saltholdige opløsninger fx fra inddampning af havvand) i nærheden af hydrotermale aktive riftzoner, alternativt - som nogle geokemikere foreslår - kunne BIF være dannet ved direkte oxidation af jern vha. (ikke-fotosyntetiske) autotrofe mikrober.

BIF uden detritiske komponenter har afsløret havvandskemien, hvorfra de kemisk var udfældet. Fx viser sjældne jordarter

Et Snebold-Jord-scenario er blevet brugt til at forklare genkomsten af Den Store Iltkatastrofe $i$ den sene neoproterozoiske periode for mellem 750-540 millioner àr siden. (Kilde: http://img243. imageshack.us/img243/7126/ snowyhw7.jpg)

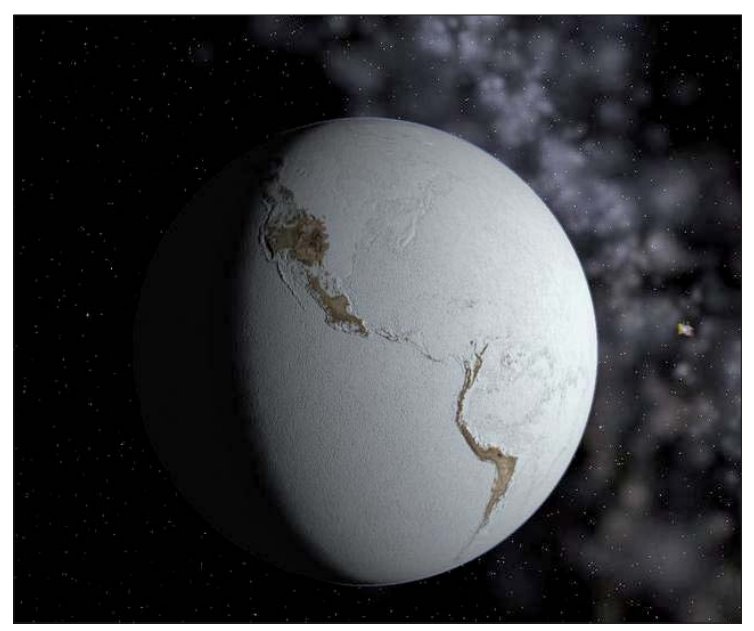

(rare earth element: REE) tydeligt typiske særpræg for havvand med let REE-forarmning over middel REE og svær REE og med positive europium-anomalier (Eu), der indikerer input af hydrotermale udslip i større mængder af disse grundstoffer inklusive jern.

Stadiet mellem 1,85 mia. år og 0,85 mia. år Afslutningen af BIF-aflejringen for $\sim 1,8$ mia. år siden er tilskrevet iltningen af de dybe oceaner og/eller udviklingen af dybe sulfidoceaner ${ }^{8}$. Modellen med de mesoproterozoiske oceaner er blevet kendt som "Canfield Oceanet". Canfield påpegede, at tilførslen af $\mathrm{O}_{2}$ til de dybe have i løbet af denne periode næsten helt sikkert var meget mindre, end den er i dag. $\mathrm{O}_{2}$-indholdet $\mathrm{i}$ havvand ville således være blevet opbrugt under dets passage fra overfladen og nedefter. Dybhavet ville derfor være blevet iltfrit eller euxinisk (dvs. tilhørende et miljø med begrænset cirkulation med stillestående eller anaerobe forhold), og jern på divalent form, der tilførtes havene via hydrotermale systemer, ville være blevet titrerede som sulfider, som så blev aflejret tæt på de hydrotermale centre. Et sådant scenarium kunne muligvis forklare manglen på båndede jernformationer i dette tidsrum (figuren på side 17).

Sen neoproterozoisk iltning $\mathbf{0 , 8 5 - 0 , 5 4}$ mia. De måske tre største istider, som man kender til, dominerede denne periode i Jordens historie, og disse istider kan meget vel have været efterfulgt af usædvanligt varmt kli$\mathrm{ma}^{13}$. Evolutionen brød igennem og kulminerede i fremkomsten af dyr og den biologiske eksplosion nær grænsen mellem Kambrium og Prækambrium ${ }^{10,11}$. Iltindholdet kan være steget til 20\% lignende det, vi har $i$ atmosfæren i dag. Denne periode er igen
Indtil 1992 blev det antaget, at de sjceldne, yngre båndede jernformationer reprosenterede uscedvanlige betingelser, hvor den lokale iltkoncentration var lav, og jernrigt vand kunne dannes og siden komme i forbindelse med iltet vand. En anden forklaring af disse
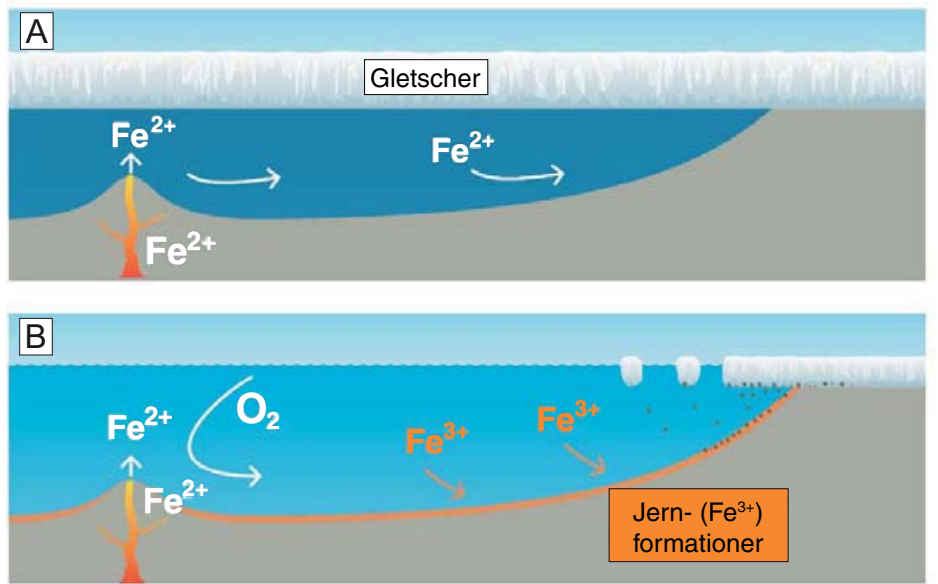
sene forekomster er genstand for megen diskussion som del af Snebold Jord-hypotesen. Denne hypotese siger, at et tidligt cekvatorialt superkontinent (Rodina) var fuldstcendigt dcekket under en istid (hvilket indeborer, at hele planeten var frosset ved overfladen til en dybde af adskillige kilometer). I så fald har Jordens frie ilt måske varet fuldstcendig borte under en alvorlig istid for ca. 750 til 580 millioner år siden. Opløst jern samlede sig så i iltfattige oceaner ( $f x$ fra hydrotermale skorstene). Efter optøningen af Jorden blev havene igen iltet, hvorved jernet endnu engang blev udfceldet. (Grafik: illustrationen er modificeret let efter en figur fra en artikel af Christiansen og medforfattere ${ }^{19}$ ) 
karakteriseret ved tilsynekomsten af jernformationer (figuren side 17) koblet sammen med tilstedeværelsen af gletscherpåvirkede (diamiktitiske, dvs. konglomerater eller breccier med ringe sortering) sedimentære bjergarter, og det ser ud til, at udfældningen af jernrige sedimenter har fundet sted efter de respektive gletscheres tilbagetrækning, da den nye atmosfære så at sige "gødede" oceanerne med ilt, efter de blev isfrie (figuren nederst side 18). Som en konsekvens af denne havvandsiltning akkumuleredes divalente ioner under glaciationerne og var i stand til at oxidere og udfælde som jernoxyhydroxider i de lavere, kystnære miljøer ved datidens landmasser.

Krom-isotoper sporer atmosfærens iltning Krom-isotopsystemet

Krom befinder sig i gruppen med overgangsmetaller og bliver undersøgt med fornyet interesse pga. nylige variabilitetsmålinger i grundstoffets talrige stabilisotoper ${ }^{12,13}$. (I løbet af de tre år, hvor forfatteren har været i gang med den grundlæggende del af forskningsprogrammet, har han udviklet et nyt sporingssystem, der formentlig kan forklare fluktuationerne $i$ atmosfærisk iltning gennem geologisk tid. Teknikken er baseret på brugen af krom-isotoper anvendt på båndede jernformationer).

Krom er med sine fire stabilisotoper (massenumre 50, 52, 53 og 54) interessant pga. den variable redox-kemi $\left(\mathrm{Cr}^{3+}\right.$ versus $\mathrm{Cr}^{6+}$ ) i naturligt og i forurenet vand. I bjergarter forekommer substitution med $\mathrm{Cr}$ næsten altid i oxider, oxyhydroxider eller i silikater som en +3-kation $\left(\mathrm{Cr}^{3+}\right)$ med kraftig præference for oktaedrisk koordination. Krom er næsten uopløseligt i +3-oxidationstilstanden i typiske næsten neutrale vandige opløsninger. I modsætning til $\mathrm{Cr}^{3+}$ danner $\mathrm{Cr}^{6+}$ opløselige, tetraedriske oxyanioner, $\left[\mathrm{CrO}_{4}\right]^{2-},\left[\mathrm{HCrO}_{4}\right]^{-}$, og $\left[\mathrm{Cr}_{2} \mathrm{O}_{7}\right]^{2-}$, hvilket gør denne form af krom ganske anvendelig $\mathrm{i}$ industrien til $\mathrm{fx}$ galvanisering.

Den mobile $\mathrm{Cr}(\mathrm{VI})$-anion $\left(\mathrm{HCrO}_{4}^{-}\right)$er den mest termodynamisk stabile kromform i ligevægt med den luft, vi har i dag. Oxidation af $\mathrm{Cr}(\mathrm{III})$ til $\mathrm{Cr}(\mathrm{VI}) \mathrm{i}$ jord afhænger af samtidig tilstedeværelse af $\mathrm{Cr}$ (III) (almindeligvis bundet som $\mathrm{FeCr}_{2} \mathrm{O}_{4}$ ) og manganoxider (der katalyserer $\mathrm{Cr}(\mathrm{III})$-oxidation). Når først $\mathrm{Cr}(\mathrm{VI})$ bliver mobiliseret under oxidativ forvitring, er den ligeså mobil som kromat- $\left(\mathrm{CrO}_{4}^{2-;}\right.$, basisk $\left.\mathrm{pH}\right)$ og dikromat- $\left(\mathrm{HCrO}_{4}^{-}\right.$; sur $\left.\mathrm{pH}\right)$ ioner, som tilføres oceanerne ved transport ved flodbreder. Dette er et betydeligt mindre bidrag af $\mathrm{Cr}$ fra atmosfæriske og hydrotermale udstrømningskilder. I nutidens oceaner ligger koncentrationerne af totalt opløst $\mathrm{Cr}$ i området af 2 til $10 \mathrm{nM}$ med en relativt kort levetid på 2,5 til 4 x $10^{4}$ år.

$\mathrm{Cr}(\mathrm{VI})$ kan reduceres til $\mathrm{Cr}$ (III) af mikrober og via vandige $\mathrm{Fe}(\mathrm{II})$ - og Fe(III)-førende mineraler ${ }^{12}$ (ligning 1). Oxidationen af $\mathrm{Fe}$ (II) (aq) vha. Cr (VI) er da også hurtigere
Skema over kroms over fladekemi. Oxidation af Cr(III) i jordbunden katalyseres af $\mathrm{MnO}_{2}(1)$ og fraktioneres positivt af $\mathrm{Cr}(\mathrm{IV})^{12}$, optages $i$ vandfasen (grundvand, floder), hovedsageligt som $\mathrm{HCrO}_{4}$-komplekser, og strømmer til sidst ud $i$ havet. Abiotisk reduktion af $\mathrm{Cr}(\mathrm{IV})$ af opstrømmende $\mathrm{Fe}(I I)^{16}$ (2) er effektiv, hurtig og fuldstoendig, og efterfølgende reaktioner mellem $\mathrm{Cr}$ med $\mathrm{Fe}$-Cr-oxyhydroxider (3) er en vigtig vej til fjernelse af Cr fra havvandet og ind i sedimentcere miljøer. Det positivt fraktionerede $\mathrm{Cr}\left(\mathrm{\delta}^{53} \mathrm{Cr} \sim-0,3-4,9 \%\right.$; dette arbejde) $i$ bån-

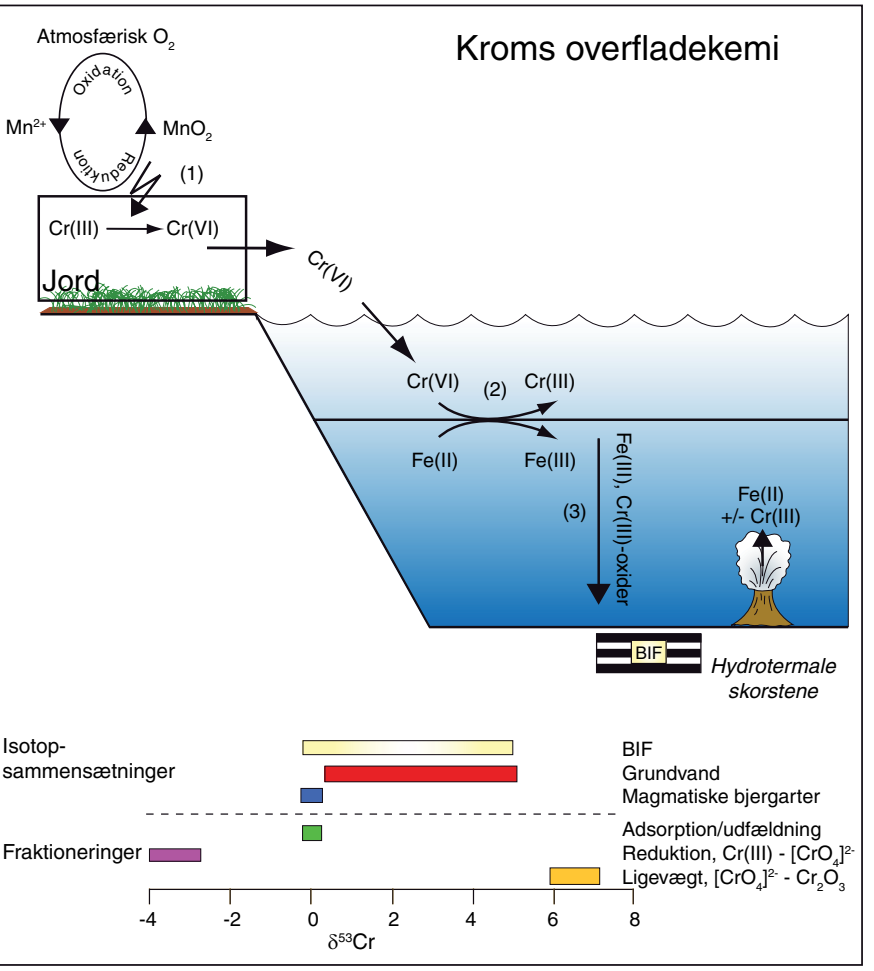

dede jernformationer og Fe-rig chert afspejler derved tilgangen af Cr til floderne. For nylig er biotisk (bakteriel) reduktion af $\mathrm{Cr}(I V)$ observeret med et Cr isotopskifte $\left(\Delta^{53} \mathrm{Cr}_{\mathrm{Cr}(I I I)-\mathrm{Cr}(\mathrm{VI})} \mathrm{på}\right.$ op mod $-4,1 \%$. Adsorption og kompleksdannelse af Cr(III) og i mindre grad Cr(VI), pa eller med organiske og uorganiske partikler er ikke ledsaget af et Cr-isotopskifte. Cr(III)-tilførsel til havvand fra hydrotermale skorstene betragtes som lille, og Cr-isotopsammenscetningen af denne andel afspejler formentlig $\delta^{53} \mathrm{Cr}$ vardierne på $\sim 0,15 \%$ o typisk for magmatiske højtemperaturreservoirer ${ }^{20}$. Dannelse af Cr(III) tilbage til Cr(IV) fra sedimenter til havvand er igen kun mulig ved $\mathrm{MnO}_{2}$-katalyse. (Grafik: UVH modificeret efter Frei et al. (2009)21)

end med ilt selv under velgennemluftede og høje pH-forhold. Dette betyder, at ved

tilstedeværelsen af $\mathrm{Fe}(\mathrm{II})$ reduceres $\mathrm{Cr}(\mathrm{VI})$ effektivt til Cr(III). Cr(III) nedbrydes/om-

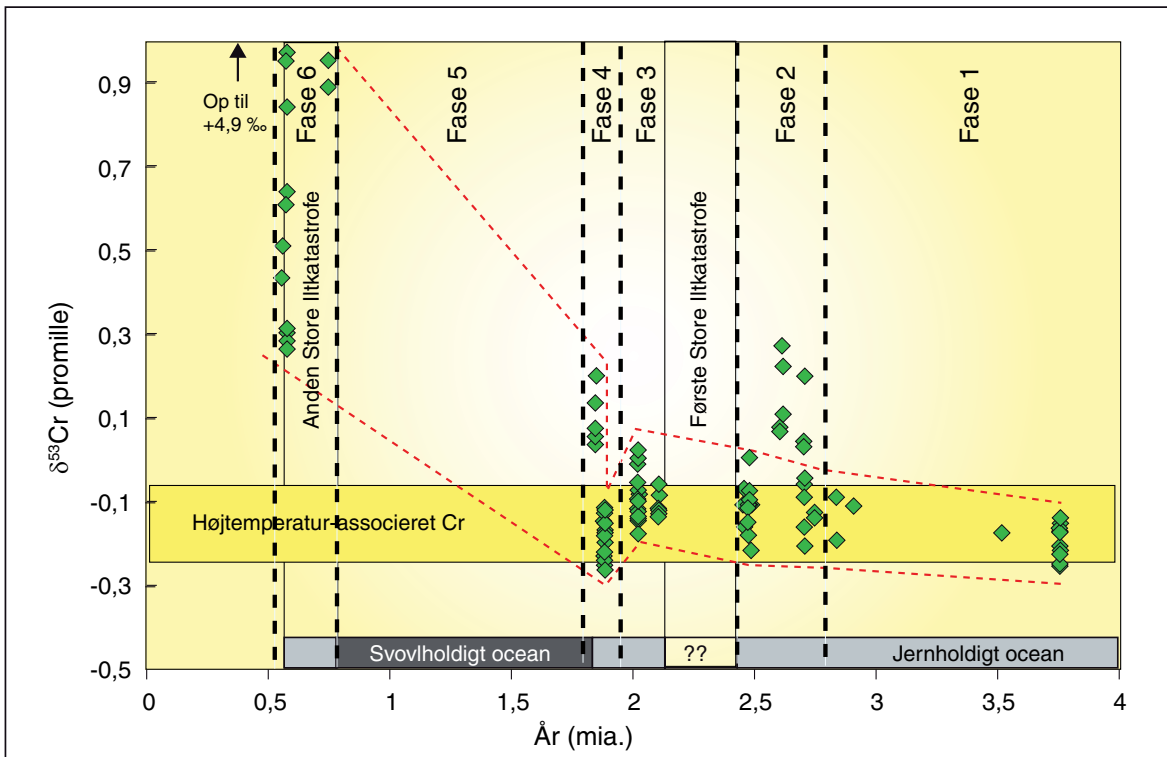

Graf der viser nøglebegreberne for den proekambriske historie for hexavalent krom $i$ havvand. $\delta^{53} C r$-vardierne (udfyldte, grønne diamantsymboler) for BIF vs. alder (22 lokaliteter $i$ det hele; høje vardier op til +4,9\%o fra neoproterozoisk Fe-rig chert plotter uden for grafen). 6 faser (separeret af stiplede vertikale linier) er identificeret og sammenlignet med kemien for dybhavsoceaner ${ }^{8}$. De lysegrå områder afbilder hhv. den forste og den anden Store Iltkatastrofe beskrevet ved andre redox-sensitive tracere. Det horisontale, rektangulcere felt skitserer $\delta^{53} \mathrm{Cr}$-vaerdierne for magmatiske Cr(III)-rige årer og mineraler dannet under høje temperaturer ${ }^{20}$. Data er opnået ved at bruge delta-notationen ifølge den certificerede "National Bureau of Standards Cr-reference standard" SRM 979, defineret som $\delta^{53} \mathrm{Cr}=$ $\left.1000 x\left[\left({ }^{53} \mathrm{Cr} /{ }^{52} \mathrm{Cr}\right)_{\text {prove }}\left({ }^{53} \mathrm{Cr} /{ }^{52} \mathrm{Cr}\right)_{\text {SRM 979 }}\right)-1\right)^{13}$. (Grafik: UVH modificeret efter Frei et al. (2009)) 
dannes(?) efterfølgende på effektiv vis til $\mathrm{Fe}(\mathrm{II})-\mathrm{Cr}(\mathrm{III})-$ oxyhydroxider pga. meget lav opløselighed af $\mathrm{Fe}, \mathrm{Cr}(\mathrm{OH})_{3}$-faststoffer. Noget $\mathrm{Cr}(\mathrm{III})$ kan blive regenereret (genmobiliseret?) og mistes fra sedimenterne som et resultat af jernoxid-reduktion, men som på land reoxideres $\mathrm{Cr}(\mathrm{III})$ hurtigt til $\mathrm{Cr}(\mathrm{VI}) \mathrm{i}$ en katalytisk reaktion med $\mathrm{MnO}_{2}$.

$\mathrm{Cr}(\mathrm{VI})(\mathrm{aq})+3 \mathrm{Fe}(\mathrm{II})(\mathrm{aq}) \rightarrow \mathrm{Cr}(\mathrm{III})(\mathrm{aq})+$ $3 \mathrm{Fe}(\mathrm{III})(\mathrm{aq})$

Under ligevægt beriges $\mathrm{Cr}(\mathrm{VI}) \mathrm{O}_{4}{ }^{2-}$-anionen med op til $7 \%$ ved stuetemperatur i ${ }^{53} \mathrm{Cr}$ sammenlignet med samtidigt forekommende forbindelser, der indeholder Cr(III). Derfor vil vandige miljøer lige under overfladen have positive $\delta^{53} \mathrm{Cr}$-værdier. Selvom isotopsammensætningen af $\mathrm{Cr}$ i havvand endnu ikke er blevet målt, vil det positive grundvandssignal for $\mathrm{Cr}(\mathrm{VI})$ sandsynligvis blive overført til havet, idet efterfølgende optagelse af Cr på partikler (som kan forekomme $\mathrm{i}$ jorden og i floder) ikke producerer nogen isotopeffekter. Den mikrobielle reduktion af $\mathrm{Cr}(\mathrm{VI})$ frembringer isotopskift op til $-4,1 \%$ og er sammenlignelige med dem, der produceres under uorganisk reduktion ${ }^{12}$. Dette vil potentielt berige den tungere isotop i det tilbageblevne, ureagerede og opløste $\mathrm{Cr}(\mathrm{VI})$. Pga. den effektive afsondring af $\mathrm{Cr}(\mathrm{VI})$ under reduktionen af $\mathrm{Cr}$ og den efterfølgende udfældning af $\mathrm{Cr}$ (III) med Fe-oxyhydroxider bør de stabile Cr-isotop-signaturer for de kemisk udfældede Fe(III)-rige sedimenter alligevel afspejle havvandet, hvorfra jernoxiderne blev udfældet. Overfladekemien for $\mathrm{Cr}$ og dens geokemi for stabilisotoper er opsummeret i figuren øverst på side 19 .

Forudsætningen, for at $\mathrm{Cr}$-isotoper registrerer tilstedeværelsen af $\mathrm{Cr}(\mathrm{VI}) \mathrm{i}$ havvand, er en overvægt af opløst $\mathrm{Fe}(\mathrm{II})$, som optræder reducerende. Derfor skulle isotopsammensætningen af $\mathrm{Cr}$ i gamle jernrige sedimenter give en førsteordens-proxy for tilstedeværelsen af $\mathrm{Cr}(\mathrm{VI})$ i overfladevandet fra gammel tid og således historien for den oxiderede forvitring af $\mathrm{Cr}$ på land. Denne fremgangsmåde skulle være relativt upåvirket af de to typer af jernige kemiske sedimenter og det palæomiljø, som de blev aflejret i. Med andre ord kan de isotopiske egenskaber for forvitringens udgangsprodukter blive overført til havet og blive fastholdt og bevaret uændret i geologisk tid. Det at måle krom-isotopernes egenskaber i jernformationer med forskellige aldre er således et vindue mod atmosfærens iltningstilstand, der udvikler sig løbende. Vi har taget et langt kig gennem dette vindue (figuren nederst på side 19) og fundet nogle enkelte overraskelser. En af dem er beviset for forhøjet, men stadig lavt iltindhold i atmosfæren længe før Den store Iltkatastrofe. Berigelse af ${ }^{53} \mathrm{Cr}$ i jernformationer bekræfter alle den biologiske produktion af ilt vha. fotosyntese i hvert fald 300 millioner år før Den Store Iltkatastrofe. Denne påstand

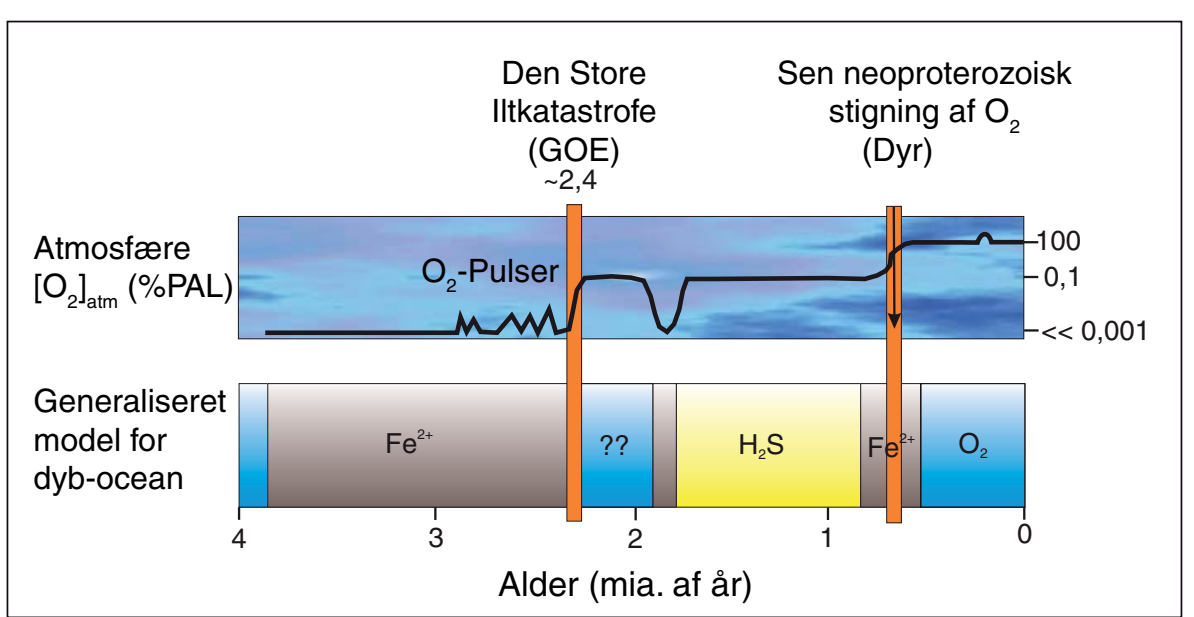

En stigning i moengden af atmosfarisk ilt for ca. 2,4 mia. år siden under Den Store iltkatastrofe faldt sammen med ophøret af de konstante og langvarige, jernrige $\left(\mathrm{Fe}^{2+}\right)$ og iltfattigeforhold i dybhavet. Talrige undersøgelser peger dog på kortvarige stigninger i iltindholdet et godt stykke tid før Den Store Iltkatastrofe - og beviser peger på tidlig, iltproducerende fotosyntese. Vores analyse af krom-isotop-forholdene i jernformationerne ${ }^{21}$ antyder, at genkomsten af et jernrigt ocean, der toppede for ca. 1,9 mia. år siden, blev udløst af et dramatisk fald i iltindhold-måske til vaerdier, der noermede sig dem, der fandtes i atmosfceren for Den Store Iltkatastrofe. Det efterfølgende 1 milliard år eller mere med tilstedevcerelsen af hydrogensulfid $\left(\mathrm{H}_{2} \mathrm{~S}\right)$ overalt i dybhavsoceanet kan vare følgen af en stigning $i$ atmosforisk ilt. Et stort skridt i iltningen fulgte herefter med dyrelivets begyndelse. Iltkoncentrationerne er givet i procent i forhold til det nutidige atmosfceriske niveau (PAL). (Grafik: Figur modificeret efter Lyons og Reinhard22).

falder også i god jord hos dem, der er kommet til samme konklusion ad andre veje $\mathrm{e}^{14,15}$ og mishager $\mathrm{dem}^{16}$, der mener, at den første betydelige mængde ilt $\mathrm{i}$ atmosfæren i forbindelse med Den Store Iltkatastrofe markerede den første produktion.

Det andet overraskende resultat af vores grundforskning var observationen, at i det mindste lokalt synes iltniveauet i Jordens overfladevande at have aftaget i tiden før den volumenmæssigt store optræden af båndede jernformationer for ca. 1,85 mia. år siden formentlig ved niveauer så lave som dem, der karakteriserede oceanernes overflade før Den Store Iltkatastrofe (figuren ovenfor). Historien kulminerer i det størst observerede skift i data fra kromisotoper for ca. 750 mio. år siden, hvilket svarer til et stort spring i atmosfærisk ilt i mængder, der bød de første dyr velkomne.

\section{Konsekvenser}

Iltens rolle i klimaændringerne er indiskutabel. Forståelsen for iltens udvikling i atmosfære og hydrosfære og dens indvirkning på forvitring af landmasserne, dens ernæringsmæssige tilførsel til havet og for udviklingen af liv er vital, således at en bedre forståelse for kompleksiteten af dens cyklus måske kan hjælpe os til at forstå klimaforandringerne $\mathrm{i}$ dag og dem, der er $\mathrm{i}$ vente $\mathrm{i}$ fremtiden. Det, vi mangler, er en faktisk forståelse af, hvad der udløser frembringelsen af ilt før og nu. En nærmere undersøgelse af sammenfaldende begivenheder af geologisk voldsomme begivenheder, der har ændret dynamiske processer på Jorden som fx sub- duktioner, opsprækning af kontinenter, vulkansk aktivitet på overfladen og sidst, men ikke mindst årsager ude fra rummet såsom meteorit- og kometnedslag, der kan hjælpe med til at udrede kompleksiteten af dette emne. Det at spore ilt i vores fortid, som det er gjort i dette forskningsprojekt, er et første skridt fremad i retningen mod målet.

\section{Referencer:}

1. Wilde, S. A. et al. Evidence from detrital zircons for the existence of continental crust and oceans on the Earth 4.4Gyr ago Nature 409, 175-178 (2001).

2. Farquhar, J. \& Wing, B. A. Multiple sulfur isotopes and the evolution of the atmosphere Earth and Planetary Science Letters 213, 1-13 (2003).

3. Bekker, A. et al. Dating the rise of atmospheric oxygen Nature 427, 117-120 (2004). 4. Bekker, A. \& Kaufman, A. Oxidative forcing of global climate change: A biogeochemical record across the oldest Paleoproterozoic ice age in North America Earth and Planetary Science Letters 258, 486-499 (2007).

5. Condie, K. C. Episodic continental growth and supercontinents: a mantle avalanche connection? Earth and Planetary Science Letters 163, 97-108 (1998).

6. Isley, A. E. \& Abbott, D. H. Plume-related mafic volcanism and the deposition of banded iron formation Journal of Geophysical Research-Solid Earth 104, 15461-15477 (1999).

7. Holland, H. D., The chemical evolution 
of the atmosphere and oceans. (Princeton Univ. Press, New York, 1984).

8. Canfield, D. E. A new model for Proterozoic ocean chemistry Nature 396, 450-453 (1998).

9. Hoffman, P. F. et al. A Neoproterozoic Snowball Earth Science 281, 1342-1346 (1998).

10. Knoll, A. H. The geological consequences of evolution Geobiology 1, 3-14 (2003). 11. Canfield, D. E., Poulton, S. W. \& Narbonne, G. M. Late-Neoproterozoic deepocean oxygenation and the rise of animal life Science 315, 92-95 (2007).

12. Ellis, A. S., Johnson, T. M. \& Bullen, T. D. Chromium isotopes and the fate of hexavalent chromium in the environment Science 295, 2060-2062 (2002).

13. Schauble, E., Rossman, G. R. \& Taylor,
H. P. Theoretical estimates of equilibrium chromium-isotope fractionations Chemical Geology 205, 99-114 (2004).

14.Brocks, J. J. et al. Archean molecular fossils and the early rise of eukaryotes Science 285, 1033-1036 (1999).

15. Anbar, A. D. et al. A whiff of oxygen before the Great Oxidation Event? Science 317, 1903-1906 (2007).

16. Rasmussen, B. et al. Reassessing the first appearance of eukaryotes and cyanobacteria Nature 455, 1101-1104 (2008).

17. Love, G. D. et al. Fossil steroids record appearance of Demospongiae during the Cryogenian period Nature 457, 718-721 (2009).

18. Canfield, D. E. The early history of atmospheric oxygen: Homage to Robert A. Garrels Annual Review of Earth and Plane- tary Sciences 33, 1-36 (2005).

19. Christiansen, J. L., Stouge, S. \& Harper, D. A. T. Dengang jorden frøs til is Naturens Verden 11, 32-43 (2006).

20. Schoenberg, $R$. et al. The stable $\mathrm{Cr}$ isotope inventory of solid Earth reservoirs determined by double spike MC-ICP-MS Chemical Geology 249, 294-306 (2008).

21. Frei, R. et al. Fluctuations in Precambria atmospheric oxygenation recorded by chromium isotopes Nature 461, 250-253 (2009).

22. Lyons, T. W. \& Reinhard, C. T. Oxygen for heavy-metal fans Nature 461, 179-181 (2009).

Denne artikel er oversat fra engelsk til dansk af Ulla Vibeke Hjuler og kan rekvireres på originalsproget via redaktionen.

\section{Kort nyt}

Ingen endelig klimaaftale i København Intet tyder på, at der under klimakonferencen i København i december bliver underskrevet en endelig aftale til afløsning for Kyoto-protokollen. FNs klimachef Yvo de Boer erklærer, at der stadig er for mange uafklarede punkter, der mangler at blive færdigforhandlet, før landene kan skrive under.

Barack Obama kommer næppe til København, idet Kongressen ikke kan sende ham af sted med et klart mandat, så længe rammerne for en aftale langt fra er på plads. Yve de Boer lægger i stedet op til, at man under klimatopmødet i København bliver enige om selve strukturen af en ny aftale, hvorefter alle detaljer forhandles på plads $\mathrm{i}$ løbet af 2010. Hvis der under topmødet kan blive enighed om en rammeaftale, der fastlægger principperne for de videre forhandlinger, er der realistisk håb om, at en endelig global klimaaftale kan forhandles på plads inden for et års tid.

Klimaminister Connie Hedegaard fik 21. oktober på et møde blandt EU's klima- og miljøministre et klart EU-mandat til på EU's vegne på topmødet i København at forhandle langsigtede reduktioner af drivhusgasser igennem.

\section{$J P / S L J$}

\section{Nationalpark i Mols Bjerge}

29. august indviede dronningen og miljøminister Troels Lund Poulsen den nye nationalpark Mols Bjerge på det sydlige Djursland. Lokale lodsejere har længe for- gæves kæmpet indædt mod nationalparken, som de føler sig tvunget ind i. De frygter, at deres jorder fremover vil blive overrendt af tusindvis af turister. Flere lodsejere føler, at deres jorde er blevet mere eller mindre eksproprieret. Pladser i den nyetablerede bestyrelse for nationalparken har ikke tilfredsstillet lodsejerne.

Nationalpark Mols Bjerge har fået 42 mio. kr. fra Arbejdsmarkedets Feriefond, Syddjurs Kommune og Skov \& Naturstyrelsen. Pengene skal bl.a. bruges til at anlægge en $27 \mathrm{~km}$ lang cykelsti rundt $\mathrm{i}$ området.

$J P / S L J$

\section{Jordskælv på Samoa}

$190 \mathrm{~km}$ syd for den amerikanske ø Samoa og $35 \mathrm{~km}$ nede i undergrunden havde et jordskælv, der blev målt til 7,9 på Richterskalaen, sit epicenter d. 29. september. Skælvet frembragte en Tsunami, der væltede ind over Samoa og forårsagede voldsomme ødelæggelser. Myndighederne meldte senere om 123 omkomne.

\section{Politiken/SLJ}

\section{Isen omkring Nordpolen vokser}

Isen omkring Nordpolen er nu vokset $i$ to år i træk siden september 2007, hvor isen kun dækkede 4,8 mio. $\mathrm{km}^{2}$. Ifølge data fra det amerikanske National Snow and Ice Data Center dækkede isen i Arktis omkring 5,5 mio. $\mathrm{km}^{2}$ i september i år.

Der er imidlertid uenighed iblandt forskere om isens tykkelse, eftersom nogle forskere hævder, at isen i dag er tyndere end tidligere. Vurderingerne består i avancerede computerprogrammer, som nogle forskere sætter deres lid til, men som andre sætter spørgsmålstegn ved. Imidlertid er der blandt forskere enighed om, at isens udbredelse og størrelse - endnu - hænger sammen med naturlige variationer i klimaet.

$J P / S L J$

\section{Ny ring omkring Saturn}

Amerikanske astronomer har med NASA's Spitzer-teleskop opdaget en ny megaring omkring Saturn. De mener, at ringen er opstået ud fra en lille, fjern måne ved navn Phoebe tæt ved planeten. Phoebe kredser om planeten og har en bredde på kun 214 $\mathrm{km}$. Phoebe har sandsynligvis forsynet ringen med fragmenter af støv og is. Astronomerne har beskrevet fænomenet i det britiske tidsskrift Nature.

AFP/SLJ

\section{Løkke mødte Obama}

Statsminister Lars Løkke Rasmussen benyttede Barack Obamas ankomst til København i forbindelse med afstemningen i Bella Centret om placeringen af OL i 2016 til i statsministeriet at udveksle informationer med henblik på klimatopmødet i København i december. Under mødet deltog Obamas toprådgiver i klimaspørgsmål Todd Stern og tre andre rådgivere. Lars Løkke Rasmussen havde sin klimarådgiver med. Derudover deltog udenrigsminister Per Stig Møller samt hans departementschef. 